\title{
Frequency of peri-intraventricular hemorrhage and its associated factors in premature newborns
}

\author{
Frequência de hemorragia peri-intraventricular e seus fatores associados em recém-nascidos \\ prematuros
}

Evelyn Arrais Guzman¹, José Ricardo Dias Bertagnon², Yara Juliano ${ }^{3}$

\begin{abstract}
Objective: To identify the frequency of intracranial hemorrhage and its associated factors in premature newborns. Methods: A crosssectional study based on a survey of medical records of premature neonates submitted to transfontanellar ultrasound at a hospital located in a southern neighborhood of the city of São Paulo, in 2007. Results: A $50 \%$ rate of intracranial hemorrhage was found among premature newborns submitted to transfontanellar ultrasound, and $15.35 \%$ among all premature babies born in this hospital in 2007 . The statistically significant factors associated to intracranial hemorrhage were gestational age less than 32 weeks, absence of prenatal care, invasive mechanical ventilation, infection, blood transfusion, hyaline membrane disease, hyponatremia and hyperglycemia. Conclusions: The frequency of peri-intraventricular hemorrhage was $50 \%$ in patients at risk and $15.35 \%$ among all premature babies; the associated factors were gestational age less than 32 weeks, absence of prenatal care, need of invasive mechanical ventilation, infection, blood transfusion, hyaline membrane disease, hyponatremia and hyperglycemia.
\end{abstract}

Keywords: Intracranial hemorrhages/epidemiology; Risk factors; Infant, premature; Ultrasonography; Respiration, artificial

\section{RESUMO}

Objetivo: Identificar a frequência de hemorragia peri-intraventricular e levantar seus fatores associados em recém-nascidos prematuros. Métodos: Realizou-se um estudo transversal com levantamento de prontuários de recém-nascidos prematuros que realizaram ultrassonografia transfontanelar no ano de $2007 \mathrm{em}$ um hospital da periferia da zona sul da cidade de São Paulo. Resultados: Foram encontradas frequência de $50 \%$ entre os recém-nascidos prematuros que realizaram ultrassonografia transfontanelar e frequência de $15,35 \%$ dentre todos os recém-nascidos prematuros nesse hospital no ano de 2007. Observaram-se, como fatores associados à hemorragia intracraniana estatisticamente significativos, idade gestacional menor que 32 semanas, ausência de assistência ao pré-natal, necessidade de ventilação mecânica invasiva, infecção, infusão de derivados sanguíneos, doença de membranas hialinas, hiponatremia e hiperglicemia. Conclusões: A frequência de hemorragia periintraventricular foi de $50 \%$ nos pacientes de risco e de $15,35 \%$ entre todos os recém-nascidos prematuros e seus fatores associados foram idade gestacional menor que 32 semanas, ausência de assistência ao pré-natal, necessidade de ventilação mecânica invasiva, infecção, infusão de derivados sanguíneos, doença de membranas hialinas, hiponatremia e hiperglicemia.

Descritores: Hemorragias intracranianas/epidemiologia; Fatores de risco; Prematuro; Ultrassonografia; Respiração artificial

\section{INTRODUCTION}

Peri-intraventricular hemorrhage $(\mathrm{PIVH})$ represents a huge problem in premature neonates due to its frequency, severity and prognosis.

Some studies demonstrated a frequency of 13 to $29.8 \%$ in newborns younger than 32 weeks of gestational age (GA) and of up to $44.68 \%$ among all premature babies ${ }^{(1-6)}$.

PIVH occurs more often in premature neonates for having the subependymal germinal matrix, an immature tissue consisted by germinative cells, located in the subependymal region of the lateral ventricle anterior horns. This tissue is highly vascularized, and the vessels have thin walls and are subject to damage as a consequence to variations in brain blood flow. Bleeding may be confined to this region or break the ependymal wall and run into the lateral ventricle. The subependymal germinal matrix is not found in neonates born at term,

\footnotetext{
Study carried out at Hospital Geral do Grajaú da Faculdade de Medicina da Universidade de Santo Amaro - UNISA, São Paulo (SP), Brazil.

${ }^{1}$ Medical student - 6th year at Faculdade de Medicina da Universidade de Santo Amaro - UNISA, São Paulo (SP), Brazil.

2 PhD; Neonatologist of the Hospital Estadual do Grajaú Professor Liberato John Alphonse Di Dio; Full professor at Universidade de Santo Amaro - UNISA, São Paulo (SP), Brazil.

${ }^{3} \mathrm{PhD}$; Full professor of Collective Health at the Faculdade de Medicina at Universidade de Santo Amaro - UNISA, São Paulo (SP), Brazil.

Corresponding author: Evelyn Arrais Guzman - Avenida Epitácio Pessoa, 555, apto. 81 - Aparecida - CEP 11030-601 - Santos (SP), Brazil - Tel.: (13) 3238-6453 - e-mail: evelynaguzman@yahoo.com.br

Received on Feb 24, 2010 - Accepted on Jun 9, 2010
} 
since its germinative cells migrate to more superficial regions of the brain as the fetus matures ${ }^{(1,2,7-9)}$.

Many are the risk factors associated to PIVH, such as low GA, low birth weight, no prenatal use of steroids, vaginal delivery, low Apgar score at one and five minutes, need for mechanical ventilation, use of blood derivates, neonatal sepsis, hypotension, apnea, pneumothorax, hyaline membrane disease, patent ductus arteriosus, acidosis, hypercapnia, use of bicarbonate, dopamine, surfactant, umbilical catheterization, and an elevated number of endotracheal aspiration ${ }^{(2-4,10,11)}$.

In most cases, PIVH occurs in the first days of life and the clinical presentation depends on severity of the hemorrhage. Papile, in 1978, classified the PIVH into four grades, as follows: grade I: bleeding in the germinal matrix; grade II: intraventricular bleeding; grade III: intraventricular bleeding with ventricular dilation; grade IV: intraparenchymatous and intraventricular bleeding. Grades I and II are usually subclinical and, in grades III and IV, there is an abrupt decline in the neonate general state, acute anemia, bulging of the bregmatic fontanel, seizures, and the main complication is hydrocephalus ${ }^{(9)}$. Since PIVH may progress from lower grades into higher ones, early diagnosis is crucial, even in premature neonates with subclinical disease ${ }^{(1,9)}$.

The most often used diagnostic method is transfontanellar ultrasound and it is effective for both diagnosis and follow-up of these patients. The advantages are ease of performing and assessing it, mobility of the equipment and the fact that it is a noninvasive method ${ }^{(12-14)}$.

PIVH may have devastating consequences, such as learning disability, mental, visual and hearing problems, impaired speech and motor system development, hydrocephalus $(25 \%)$, cerebral palsy $(66 \%)$ and high mortality $(30 \%)^{(1-6)}$.

\section{OBJECTIVE}

The objective of this study was to identify the frequency of PIVH and its associated factors in premature neonates.

\section{METHODS}

After approval by the Research Ethics Committee of the hospital, a cross sectional, study was conducted, collecting data from the patients records at the Medical Records and Statistics Department regarding premature newborns $(\mathrm{n}=351 / 2,036$ or $17.2 \%)$. Those who underwent transfontanellar ultrasound in the period between January $1^{\text {st }}$ and December $31^{\text {st }}, 2007$ were selected according to the records from the Ultrasound Department. The initial sample had 77 patients, and
3 were excluded because the records could not be assessed, making up a sample of 74 patients.

Babies were considered premature when born before 37 weeks of GA, that is, up to 36 weeks and 6 days ${ }^{(1)}$.

The inclusion criteria for the study were those that the Service considered at risk for PIVH and led to the indication of transfontanellar ultrasound: neonates younger than 32 weeks of GA; neonates between 32 and 34 weeks of GA; no prenatal care; use of prenatal steroids; mechanical ventilation; severe anoxia; infection; metabolic disorders; neonates older than 34 weeks with severe anoxia who needed ventilation.

A protocol with the following variables was used for data collection: GA (according to Capurro or the new Ballard method) ${ }^{(15-16)}$; mode of delivery; gender; prenatal administration of steroids; prenatal care; birth weight, adopting the classification of birth weight as $\geq$ 2,500 g, between 1,501 and 2,500 g, between 1,001 and $1,500 \mathrm{~g}$, and $\leq 1,000 \mathrm{~g}$ ); weight classification according to GA (below the $10^{\text {th }}$ percentile for $\mathrm{GA}=$ small for gestational age, SGA; between the $10^{\text {th }}$ and $90^{\text {th }}$ percentile $=$ appropriate for gestational age, AGA); Apgar score for one and five minutes; need for invasive mechanical ventilation; presence of metabolic disorders (serum calcium, sodium and glucose levels); neonatal infection; use of blood products; hyaline membrane disease; wet lung syndrome; bronchopulmonary dysplasia; patent ductus arteriosus; retinopathy of prematurity; necrotizing enterocolitis; and osteopenia of prematurity.

For data input and analysis, Epi Info 6.0 software, $\chi^{2}$ test and Fisher's exact test, with a significance level $\mathrm{p}<$ 0.05 , were used.

\section{RESULTS}

A sample of 74 patients, representing $96.10 \%$ of premature neonates at risk was studied. In that, $41.9 \%$ were males; $58.1 \%$ with birth weight between 1,501 and $2,500 \mathrm{~g} ; 27.0 \%$ with birth weight between 1,001 and 1,500 g; and $10.8 \%$ weighed less than $1,000 \mathrm{~g} ; 32.4 \%$ with GA less than 32 weeks; $85.1 \%$ less than 35 weeks; $27.0 \%$ with no prenatal care; $12.2 \%$ died during hospital stay; $31.1 \%$ were SGA; $60.8 \%$ were born by vaginal delivery; $66.2 \%$ were in invasive mechanical ventilation and $9.5 \%$ received prenatal steroids.

Four patients were born at home and did not receive the Apgar score. Therefore, among the 70 remaining patients, $6.7 \%$ had one-minute Apgar score lower than 3; and 2.8\% had five-minute Apgar score lower than 5. Of the 74 patients, $13.5 \%$ had hypoglicemia; $14.9 \%$ hyponatremia; $12.2 \%$ hyperglicemia; $8.1 \%$ hypocalcemia; $63.5 \%$ neonatal infection; $86.5 \%$ hyaline membrane disease; $12.2 \%$ bronchopulmmonary 
dysplasia; $20.3 \%$ wet lung disease; $16.2 \%$ patent ductus arteriosus; $2.7 \%$ osteopenia of prematurity and $6.7 \%$ necrotizing enterocolitis. Of 42 neonates in whom fundoscopy was performed, $38.1 \%$ had retinopathy of prematurity (Table 1).

Table 1. Frequency of conditions in the studied population $(n=74)$

\begin{tabular}{lcc}
\hline Conditions & $\mathbf{n}$ & $\mathbf{F}(\%)$ \\
\hline Apgar $<3$ at first minute & 5 & 6.7 \\
Apgar $<5$ at fifth minute & 2 & 2.8 \\
Hypoglycemia & 10 & 13.5 \\
Hyponatremia & 11 & 14.9 \\
Hyperglycemia & 9 & 12.2 \\
Hypocalcemia & 6 & 8.1 \\
Neonatal infection & 47 & 64.5 \\
HMD & 64 & 86.5 \\
BPD & 9 & 12.2 \\
WLD & 15 & 20.3 \\
PDA & 12 & 16.2 \\
OPP & 2 & 2.7 \\
NEC & 5 & 6.7 \\
ROP & 16 & 38.1 \\
IMV & 49 & 66.2 \\
\hline
\end{tabular}

HMD: hyaline membrane disease, BPD: bronchopulmmonary dysplasia, WLD: wet lung disease, PDA: patent ductus arteriosus, OPP: osteopenia of prematurity, NEC: necrotizing enterocolitis, ROP: retinopathy of prematurity, IMV: invasive mechanical ventilation

Among the 74 patients studied, 37 had PIVH (50\%). There was a significant association of PIVH in premature neonates who required invasive mechanical ventilation, had no prenatal care, received blood products, had infection, hyaline membrane disease, hyponatremia according to the $\chi^{2}$ test (Table 2) and hyperglycemia according to the exact Fisher's test $=0,01405$.

No association was observed with gender, death during hospital stay, the fact of being SGA, type of delivery, the use of prenatal steroids, the one- or fiveminute Apgar score, bronchopulmonary dysplasia, wet
Table 2. Factors associated with PIVH

\begin{tabular}{lcc}
\hline Factors associated with PIVH & $\chi^{2}$ & p value \\
\hline Need of IMV & 17.458 & 0.001 \\
Absence of prenatal care & 6.852 & 0.01 \\
Presence of infection & 13.121 & 0.005 \\
Infusion of blood products & 32.291 & 0.0005 \\
Presence of HMD & 11.563 & 0.001 \\
Presence of hyponatremia & 5.232 & 0.005 \\
\hline IMV: invasive mechanical ventilation. HMD: hyaline membrane disease, PIVH: peri-intraventricular hemorrhage
\end{tabular}

lung disease, patent ductus arteriosus, osteopenia of prematurity; retinopathy of prematurity, hypocalcemia and hypoglycemia.

In regard to birth weight, no premature newborn with birth weight $>2,500 \mathrm{~g}(\mathrm{n}=3)$ had PIVH. Of the premature neonates presenting $\mathrm{PIVH}, 32.5 \%$ had a birth weight between 1,501 and $2,500 \mathrm{~g}, 75.0 \%$ of those weighing 1,001-1,500 g; and 100\% of those with birth weight below $1,000 \mathrm{~g}$. Comparing the sample to the population of premature neonates alive in the Hospital Geral do Grajaú ( $\mathrm{n}=351$ ), PIVH was observed in $4.8 \%$ of newborns weighing between 1,500 and 2,500 $\mathrm{g}$; in $27.0 \%$ of those weighing between 1,001 and $1,500 \mathrm{~g}$, in $100 \%$ of babies with weight under $1,000 \mathrm{~g}$. Considering the newborns weighing less than $1,500 \mathrm{~g}$, PIVH accounted for $7.9 \%$ (28/351) of the total number of premature neonates (Table 3 ).

Concerning GA, $87.5 \%$ of the neonates younger than 32 weeks in this study presented PIVH, and the difference is statistically significant $(p<0.0005)$ in relation to premature neonates with GA between 32 and 37 weeks. When compared to the whole population of neonates younger than 32 weeks born at this hospital in $2007(\mathrm{n}=43)$, the frequency was $48.8 \%$. Among neonates born between 32 and 37 weeks of GA, $32 \%$ presented $\mathrm{PIVH}$, with a total frequency, among the population of premature babies, equal to $15.3 \%$ (Table 4).

Table 3. Presence of PIVH per weight classification

\begin{tabular}{|c|c|c|c|c|c|c|}
\hline \multirow{2}{*}{ Weight (g) } & \multicolumn{2}{|c|}{ PIVH } & \multirow{2}{*}{ Total of cases } & \multirow{2}{*}{$\begin{array}{c}\text { Relative frequency of specific } \\
\text { PIVH/group (\%) }\end{array}$} & \multirow{2}{*}{$\begin{array}{c}\text { Total population per weight } \\
\text { range }\end{array}$} & \multirow{2}{*}{$\begin{array}{l}\text { Relative frequency }(\%) \text { in } \\
\text { premature newborns }(n=351)\end{array}$} \\
\hline & Yes & No & & & & \\
\hline$>2,500$ & 0 & 3 & 3 & 0 & 1,685 & 0 \\
\hline 1,501 to 2,500 & 14 & 29 & 43 & 32.5 & 289 & 4.8 \\
\hline 1,001 to 1,500 & 15 & 5 & 20 & 75.0 & 54 & 27.0 \\
\hline$<1,000$ & 8 & 0 & 8 & 100.0 & 8 & 100.0 \\
\hline Total & 37 & 37 & 74 & & 2,036 & 1.8 \\
\hline
\end{tabular}

Table 4. PIVH per gestational age

\begin{tabular}{|c|c|c|c|c|c|c|}
\hline \multirow{2}{*}{ GA } & \multicolumn{2}{|c|}{ PIVH } & \multirow{2}{*}{ Total } & \multirow{2}{*}{$\begin{array}{c}\text { Relative frequency of } \\
\text { specific PIVH/group (\%) }\end{array}$} & \multirow{2}{*}{$\begin{array}{c}\text { Population of premature } \\
\text { newborns }\end{array}$} & \multirow{2}{*}{ Frequency $(\%)$} \\
\hline & Yes & No & & & & \\
\hline$<32$ weeks & 21 & 3 & 24 & 87.50 & 43 & 48.83 \\
\hline $32 \mid$ - 37 weeks & 16 & 34 & 50 & 32.0 & 198 & 8.0 \\
\hline Total & 37 & 37 & 74 & 50 & 241 & 15.35 \\
\hline
\end{tabular}




\section{DISCUSSION}

The lower the GA, the more frequent the PIVH, due to immaturity of the central nervous system, and the lower the birth weight. The population of premature neonates was high in the hospital, in 2007; therefore the rate of PIVH in this population was also expected to be high, what was effectively observed. Some studies showed a frequency of 13.5 to $44.7 \%$ in patients younger than 37 weeks, 13.0 to $29.8 \%$ in younger than 32 weeks, and 13.5 to $43.0 \%$ in those less than $1,500 \mathrm{~g}^{(2,4,4,13,17)}$, similar to the data that this study presented.

The absence of prenatal care was associated to $\mathrm{PIVH}$, and this could increased premature deliveries, perinatal infection, neonatal asphyxia - all conditions related to PIVH in the literature ${ }^{(3,11)}$.

Use of mechanical ventilation, and presence of hyaline membrane disease, infection and metabolic disorders were associated to PIVH in this study and directly interfered in the genesis of this hemorrhage, for promoting sudden vasodilation and constriction leading to damage in the vascular walls of the subependymal PIVH $^{(11)}$.

The use of blood products translates the severity of the case; anemia and dehydration are associated to the disease, corroborating the data found in this study(1,4).

Some of the findings deserve special consideration. Therefore, vaginal delivery is seen as a risk factor in the literature ${ }^{(18,19)}$, but in the present study was not found as such. Cesarean section may probably diminish the injury due to the preterm vaginal delivery. As this is a teaching maternity hospital used as reference center for patients at risk, this factor was probably taken into account when choosing the type of delivery. Most babies were born by cesarean section; since there were less vaginal deliveries, there was no association with this mode of delivery. On the other hand, the baby with no history of prenatal care, whose mother arrived at the hospital in the expulsion phase (vaginal delivery), born with extremely low weight (less than 1,000 g), died early, allowing no time for the diagnosis to be made ${ }^{(3,5)}$.

There was no association with a low Apgar score or with protection with the use of prenatal steroids. These findings facts differ from the literature, but the large number of mothers with no prenatal care, and, as previously discussed, early death due to extremely low birth weight in pregnant women who arrived in the expulsion phase, associated to birth asphyxia, might have masked the association ${ }^{(11,20)}$.

Necrotizing enterocolitis and bronchopulmonary dysplasia were expected to be associated with PIVH. Like any other infection, necrotising enterocolitis produces dehydration, and due to the toxic action, causes vasodilation. Nevertheless, this association was not seen in the present study. Considering this disorder affects neonates of any birth weight, further studies with larger samples should be carried out, discriminating weight and verifying the existence of a true association. Bonchopulmonary dysplasia is a disease of premature babies who survive hyaline membrane disease and have late symptoms. It may occur when the PIVH has already subsided, what would explain the lack of association, since in this article, PIVH was considered at the moment of presentation ${ }^{(1)}$.

\section{CONCLUSION}

PIVH was found in half of the premature neonates of this study undergoing transfontanellar ultrasound, according to risk criteria. The PIVH associated risk factors that were statistically significant included GA less than 32 weeks, absence of prenatal care, need for invasive mechanical ventilation, presence of infection, infusion of blood products, hyaline membrane disease, hyponatremia and hyperglycemia.

PIVH screening proved to be mandatory in a population at risk.

\section{ACKNOWLEDGEMENTS}

To doctor Patrícia Colombo Compri and doctor Neil Ferreira Novo for the collaboration in the statistical analysis.

\section{REFERENCES}

1. Segre CA, Costa HP, Lippi UG. Perinatologia: fundamentos e prática. São Paulo: Sarvier; 2009.

2. Vural M, Yilmaz I, llikkan B, Erginoz E, Perk Y. Intraventricular hemorrhage in preterm newborns: risk factors and results from a University Hospital in Istanbul, 8 years after. Pediatr Int. 2007;49(3):341-4.

3. Redondo F, Falcó 0, Rodriguez A, Vicente C, Carande M. Hemorragia intracraneana del prematuro, frecuencia de presentación y factores de riesgo. Arch Arg Pediatr. 2003;101(4):256-60

4. Morales OL, Latorre JF, Hernandez JR, Vera LAP. Hemorragia intraventricular em niños pretérmino, incidência y factores de riesgo. Um estúdio de corte transversal. Med UNAB. 2003;6(17):57-62.

5. Mendonza AM, Kalil LF, Moog JC, Hernández AG, Ochoa JW, Hidalgo YS. Evaluación de la incidência y los factores de riesgo para hemorragia intraventricular (HIV) en la cohorte de recién nacidos prematuros atendidos en la unidade neonatal del Hospital Universitario San Vicente de Paúl, de Meddellín, en el período comprendido entre enero de 1999 y diciembre de 2004. IATREIA. 2007;20(4):341-53.

6. Roze E, Kerstjens JM, Maathuis CG, ter Horst HJ, Bos AF. Risk factors for adverse outcome in preterm infants with periventricular hemorrhagic infarction. Pediatrics. 2008;122(1):e46-52.

7. Ohlweiler L, da Silva AR, Barros SV, Riesgo R, Rotta NT. Influence of intracranial hemorrhage and neonatal seizures on the neurological and psychomotor development of premature infants at Hospital de Clínicas de Porto Alegre, Brazil. Arq Neuropsiquiatr. 2003;61 (4):902-5. 
8. Nazar Herrera N. Hemorragia intraventricular en el recién nacido prematuro. Rev Méd Hondur. 2004;72(4):205-8.

9. Papile LA, Burstein J, Burstein R, Koffler H. Incidence and evolution of subependymal and intraventricular hemorrhage: a study of infants with birth weights less than 1,500 gm. J Pediatr. 1978;92(4):529-34.

10. Badiee Z. Intraventricular hemorrhage in very low birth weight infants. Associated risk factors in Isfahan, Iran. Saudi Med J. 2007;28(9):1362-6.

11. Khodapanahandeh F, Khosravi N, Larijani T. Risk factors for intraventricular hemorrhage in very low birth weight infants in Tehran, Iran. Turk J Pediatr. 2008;50(3):247-52.

12. Farage $L$, Assis MC. Achados ultra-sonográficos da hemorragia intracraniana em recém-nascidos prematuros. Arq Neuropsiquiatr. 2005;63(3B):814-6.

13. Kadri H, Mawla AA, Kazah J. The incidence, timing, and predisposing factors of germinal matrixandintraventricularhemorrhage (GMH/IVH) in pretermneonates. Childs Nerv Syst. 2006;22(9):1086-90.

14. Kopelman BI. Ultra-som de crânio para a detecção de lesões cerebrais após procedimentos de reanimação neonatal em sala de parto [Editorial]. Rev Paul Pediatria. 2005;23(3):114-5.
15. Capurro H, Konichezky S, Fonseca D, Caldeyro-Barcia R. A simplified method for diagnosis of gestational age in the newborn infant. $J$ Pediatr. 1978;93(1):120-2.

16. Ballard JL, Khoury JC, Wedig K, Wang L, Eilers-Walsman BL, Lipp R. New Ballard Score, expanded to include extremely premature infants. J Pediatr. 1991;119(3):417-23.

17. Tavares EC, Viana MB, Machado MA, Fonseca R, Bragança CA. Alterações cerebrais em recém-nascidos pré-termos detectadas por ultra-sonografia. Rev Paul Pediatria. 2005;23(3):117-23.

18. Ahmeti F, Azizi I, Hoxha S, Kulik-Rechberger B, Rechberger T. Mode of delivery and mortality among preterm newborns. Ginekol Pol. 2010;81(3):203-7.

19. Dani C, Poggi C, Bertini G, Pratesi S, Tommaso MD, Scarselli G, et al. Method of delivery and intraventricular haemorrhage in extremely preterm infants. $J$ Matern Fetal Neonatal Med. 2010 Mar 18. [Epub ahead of print]

20. Linder N, Haskin O, Levit O, Klinger G, Prince T, Naor N, et al. Risk factors for intraventricular hemorrhage in very low birth weight premature infants: a retrospective case-control study. Pediatrics. 2003;111(5 Pt 1):e590-5. 